NBER WORKING PAPER SERIES

FISCAL LIMITS AND MONETARY POLICY

Eric M. Leeper

Working Paper 18877

http://www.nber.org/papers/w18877

\author{
NATIONAL BUREAU OF ECONOMIC RESEARCH \\ 1050 Massachusetts Avenue \\ Cambridge, MA 02138 \\ March 2013
}

Written for the Central Bank of the Republic of Turkey. Huixin Bi, Chris Sims and Todd Walker gave me useful comments. The views expressed herein are those of the author and do not necessarily reflect the views of the National Bureau of Economic Research.

NBER working papers are circulated for discussion and comment purposes. They have not been peerreviewed or been subject to the review by the NBER Board of Directors that accompanies official NBER publications.

(C) 2013 by Eric M. Leeper. All rights reserved. Short sections of text, not to exceed two paragraphs, may be quoted without explicit permission provided that full credit, including $\odot$ notice, is given to the source. 
Fiscal Limits and Monetary Policy

Eric M. Leeper

NBER Working Paper No. 18877

March 2013

JEL No. E31,E52,E62,E63

\begin{abstract}
$\underline{\text { ABSTRACT }}$
Every economy faces a "fiscal limit" that delivers the maximum government debt-GDP ratio that can be sustained without appreciable risk of default or higher inflation. But governments in advanced economies issue substantial nominal debt and nominal debt is a commitment to repay in nominal units. When such economies are approaching their fiscal limits, debt can be devalued through higher current and future inflation rates. The paper develops a simple bond market supply-demand apparatus to explain how fiscal policy can be a source of inflation, while monetary policy merely determines the timing of inflation.
\end{abstract}

Eric M. Leeper

Department of Economics

304 Wylie Hall

Indiana University

Bloomington, IN 47405

and Monash University, Australia

and also NBER

eleeper@indiana.edu 


\title{
Fiscal Limits AND Monetary Policy
}

\author{
Eric M. Leeper*
}

\section{INTRODUCTION}

Fiscal sustainability, once the exclusive concern of emerging economies, is now a prominent worry in advanced economies, large and small. Japan tops the list with a debt-GDP ratio well over 200 percent. Greece, whose sovereign debt troubles are well known, comes in with debt over 150 percent of GDP. Countries with ratios between 100 and 150 percent include Italy, Portugal, Ireland, and the United States. Major European countries are not immune: France and the United Kingdom are in the 80 -percent range, as is fiscally responsible Germany. ${ }^{1}$ These debt run ups are to a large extent understandable: the worldwide financial crisis and the prolonged and deep recession both generated automatic budget deficits and induced many countries to implement sizeable fiscal stimulus packages. But persistently sluggish economic growth in these countries, exacerbated by premature fiscal austerity moves, has prevented the normal cyclical improvement in fiscal balances.

Every economy faces a fiscal limit that delivers the maximum government debt-GDP ratio that can be sustained without appreciable risk of default or higher inflation. For both economic and political reasons, governments' ability to raise revenues is limited: tax distortions discourage economic activity and encourage tax evasion to create Laffer-curve effects that place an upper bound on revenues. Political constraints further reduce the maximum level of revenues as the electorate's intolerance of taxation generally prevents tax rates from rising to the peak of the Laffer curves. ${ }^{2}$ On the spending side, economies require some minimum level of government expenditures to function, but most societies have adopted social compacts that put a floor on spending that is well above that minimum. Taken together, these considerations imply a maximum level of primary budget surplusescall it $s^{\max }$. The expected discounted present value of the stream of maximum primary surpluses yields the maximum sustainable risk-free level of government debt.

Of course, economies are subject to shocks that cause $s^{\max }$ and discount rates to vary over time and over states of the economy. Good productivity, for example, will increase the revenues that a given tax rate generates while simultaneously raising GDP to reduce the debt-GDP ratio. Policy itself may be a source of randomness: today's government might adopt fiscal reforms that restrict the growth of government transfers, while future

\footnotetext{
* March 3, 2013. Written for the Central Bank of the Republic of Turkey. Huixin Bi, Chris Sims and Todd Walker gave me useful comments. Indiana University, Monash University and NBER; eleeper@indiana.edu.

${ }^{1}$ Data are for gross government debt as a share of GDP, from International Monetary Fund (2012a).

${ }^{2}$ Trabandt and Uhlig (2011) calculate that only very few countries - Denmark and Sweden, for examplehave labor tax rates that may exceed revenue-maximizing levels.
} 
governments might reverse those reforms. The fiscal limit, then, is not a single point: it is a probability distribution, a feature that carries important implications for thinking about fiscal sustainability. ${ }^{3}$ Intrinsic randomness in the economy will shift and alter the shape of the fiscal limit distribution, with resulting impacts on the economic decisions of private agents.

As a country's level of government debt approaches its fiscal limit, the probability rises that a country will devalue its debt in some fashion. Devaluation can occur in two ways. The first, "outright default," connects to the situation in which southern European countries now find themselves. Outright default entails reneging on some portion of outstanding debt obligations and is the only type of default available to countries who do not control their own currency or who issue debt denominated in foreign currency. Members of the European Monetary Union fall into this category, as their monetary policy is controlled by the European Central Bank, which is dominated by countries not now experiencing sovereign debt problems. A higher probability of outright default reduces the value of outstanding government bonds and raises sovereign risk premia.

A second type of devaluation is available to countries who issue nominal debt denominated in their home currency and who retain control of monetary policy. Nominal debt is a commitment to repay in nominal units, so its value depends both on expected future surpluses and on current and future price levels. A country that is at its fiscal limit no longer has the latitude to support nominal debt expansions with higher future surpluses, the maintained assumption of conventional monetarist or new Keynesian perspectives on inflation. With surpluses fixed at their upper limit, $s^{\max }$, the real value of government debt is also fixed at its maximum value. Higher nominal debt must be devalued by higher current and future price levels to ensure that its real value is consistent with the fiscal limit. ${ }^{4}$

This alternative means of devaluing outstanding debt is not much discussed because of a wide-spread misperception that so long as monetary policy has sufficient resolve to keep inflation low and stable, then fiscal inflation cannot happen. ${ }^{5}$ This article explains inflation as a means of devaluation and describes why the notion of a fiscal limit may grow increasingly relevant in advanced economies in coming decades.

\section{The Fiscal Problem}

Advanced economies today face both short-run and long-run fiscal challenges. Although these challenges are well known, briefly reviewing the data helps to put the magnitudes of the two in perspective.

\footnotetext{
${ }^{3}$ Analyses like Ghosh, Kim, Mendoza, Ostry, and Qureshi (2012) treat the fiscal limit as a point, derived by assuming governments continue to follow past behavior. But most public discussion of fiscal sustainability, epitomized by America's "Fix the Debt" movement, simply applies Goldilocks reasoning — "this debt is too high" - with little supporting analysis.

${ }^{4}$ Sims (2013) provides an insightful discussion of and contract between the two types of debt devaluation.

${ }^{5}$ Most economists believe that fiscal inflations require that the central bank systematically monetize the debt, as in Sargent and Wallace's (1981) "unpleasant monetarist arithmetic" paper. Leeper and Walker (2013) describe in detail the difference between a fiscal inflation from monetization of debt and a fiscal inflation that devalues nominal government liabilities.
} 
2.1 Fiscal Developments: Now and the Future Figure 1 reports fiscal data from the International Monetary Fund, grouping "advanced" and "emerging" economies separately. Although both sets of countries saw fiscal deficits increase beginning in 2009, the rise was far more pronounced for advanced economies. Public debt in advanced economies rose sharply, and is projected to exceed 100 percent of GDP in coming years. Emerging economies, in contrast, experienced declining levels of debt over the same period. Among advanced economies, these cyclically-induced fiscal imbalances are certainly large by historical standards.
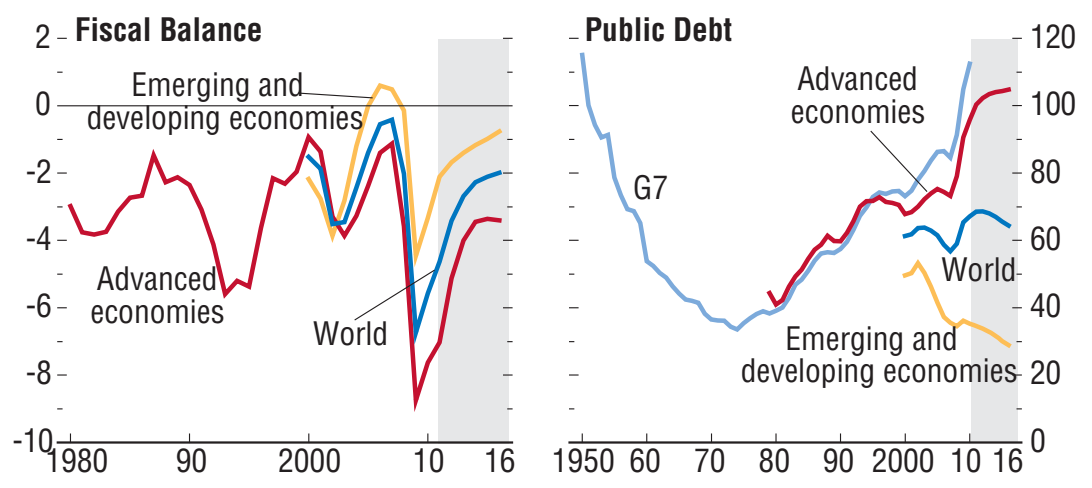

Figure 1: Fiscal deficits and public debt in percentages of GDP: Actual and projected. Source: International Monetary Fund (2012b)

Many countries, particularly members of the European Monetary Union and the United Kingdom, have reacted to these large imbalances by adopting sizeable fiscal consolidation programs. Those consolidations began even when unemployment rates were elevated, or still rising, from the 2009 recession.

This immediate fiscal problem pales by comparison to the looming crisis that most countries face. World populations are projected to continue to age. Figure 2 reports dependency ratios - the population 65 and older as a percentage of population aged 15-64 - for a variety of advanced and emerging economies. Without exception, dependency ratios are expected to at least double in these countries between now and 2050. By that latter date, four countries - Germany, Japan, Korea, and Spain — will see dependency ratios of 60 percent or higher.

The dependency ratio is a gauge of how many workers there are to support each retiree. Germany, for example, will go from $3-1 / 3$ workers per retiree today to $1-2 / 3$ workers in 2050. For countries with pay-as-you-go pension systems or other old-age benefits that are not pre-funded, a higher dependency ratio translates fairly directly into the level of "unfunded liabilities" that a country possesses. And the level of unfunded liabilities, in turn, measures the long-run fiscal stress that a country faces: either these liabilities will have to be funded in the future with higher taxes or the pension and benefits systems must be reformed to imply far lower liabilities. Either solution is politically difficult in democratic societies because they entail substantial redistributions of wealth among segments of the populace.

The degree to which the aging populations create fiscal stress appears in the debt-GDP ratio projections that figures 3 and 4 report for 12 advanced economies. Those projections, 


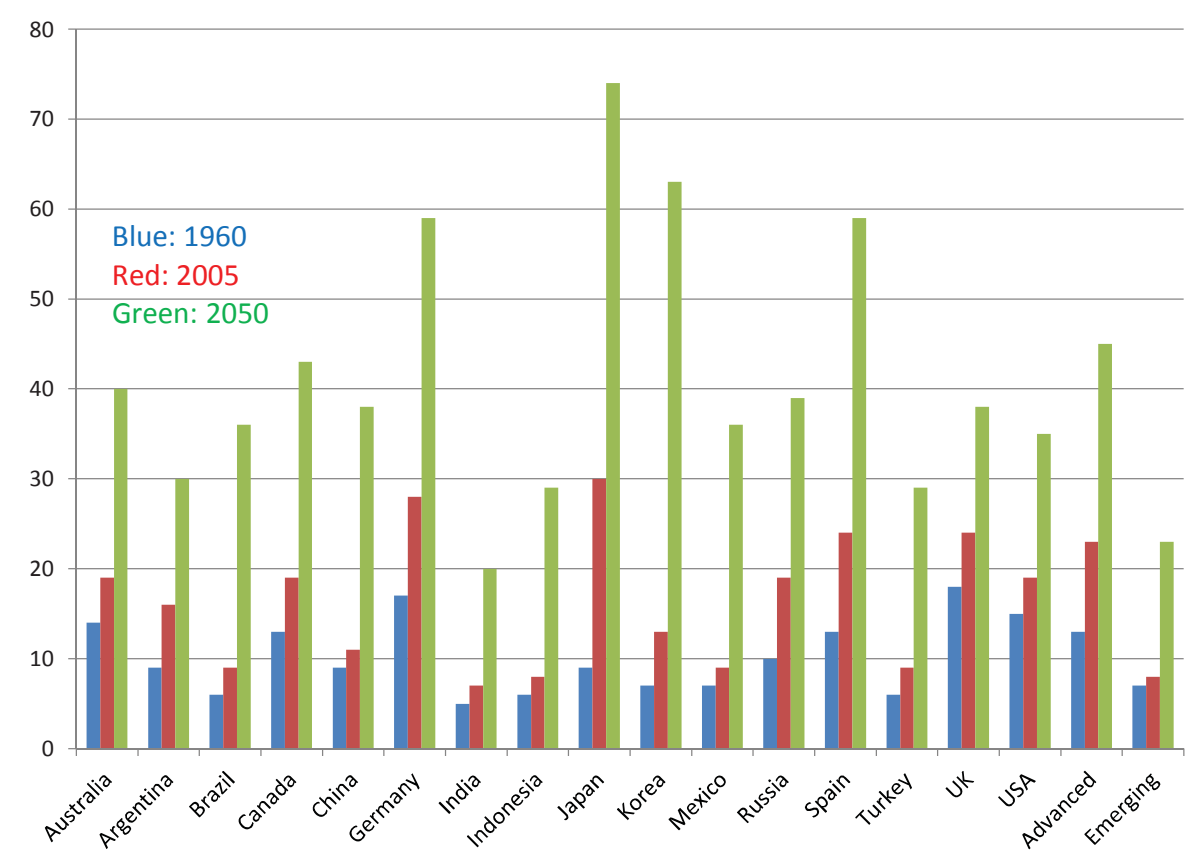

Figure 2: Dependency ratios: Population 65 and older as a percentage of population aged 15-64. Source: World Bank (2012)

constructed by the Bank for International Settlements, show that with no fiscal reforms or with fiscal reforms that do not hold age-related spending constant, debt-GDP grows exponentially. These projections extend only to 2040, but populations in many countries continue to age for decades after the projection period. ${ }^{6}$ These long-term projections place in sharp relief the short-run fiscal worries that figure 1 depicts. Yes, advanced economies face fiscal challenges today. But today's challenges are tiny compared to the fiscal stress that looms in the future.

2.2 How Will Policy Respond? Because the demographic shifts that lie in our futures are unprecedented - at least since countries implemented extensive social safety nets - it is difficult to know how government policies will adjust to the unfunded liabilities when they are realized. Some countries have been building sovereign wealth funds. Norway invests oil revenues. Australia and New Zealand have forced savings funds. Other countries, like Chile and Sweden, have adopted fiscal surplus targets with the aim of using the surpluses to pre-fund future old-age benefits.

But many governments seem to be in denial about the impending long-term fiscal stress. Should we look at how those governments are coping with their short-run fiscal challenges to extrapolate into the future? Here are a few vignettes:

- Italian Prime Minister Mario Monti, who has been credited with creating some stability in Italy's fiscal finances, steps down after former prime minister Silvio Berlusconi's

\footnotetext{
${ }^{6}$ Comparable long-term projections by the Congressional Budget Office (2010), which extend to 2082, report an "alternative policy scenario" in which debt exceeds 900 percent of GDP.
} 

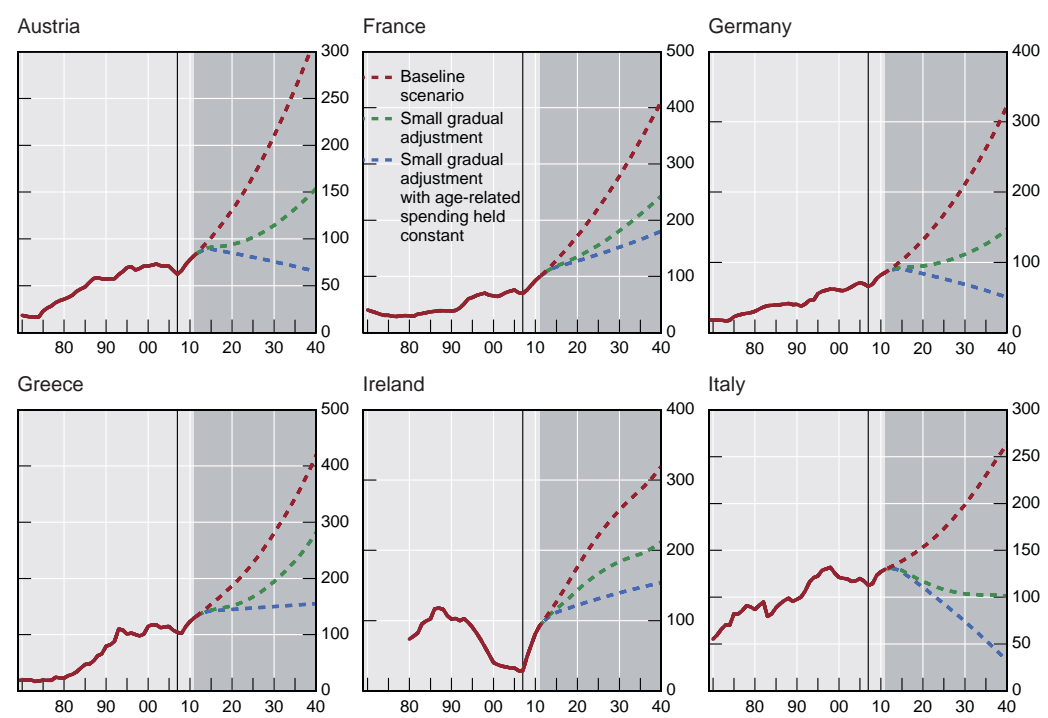

Ireland

Italy
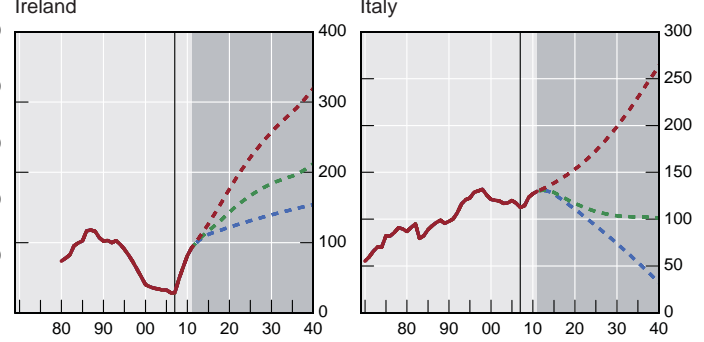

Figure 3: Debt-GDP projections: Alternative fiscal policy scenarios. Source: Cecchetti, Mohanty, and Zampolli (2010)
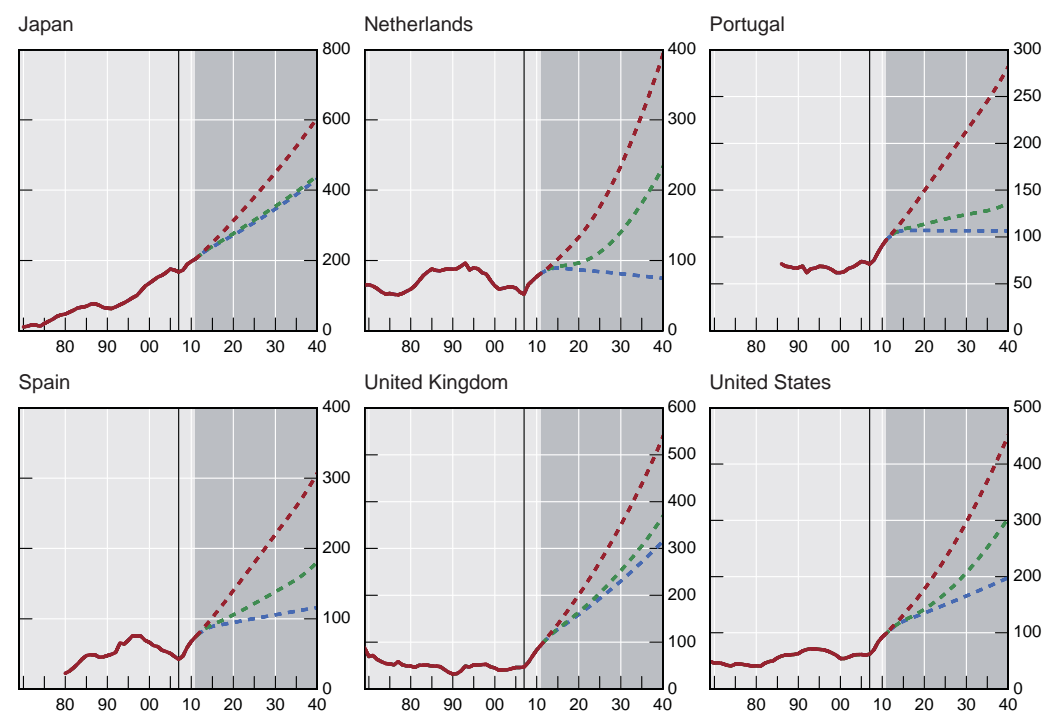

Figure 4: Debt-GDP projections: Alternative fiscal policy scenarios. Legend appears in figure 3. Source: Cecchetti, Mohanty, and Zampolli (2010)

party withdrew its support of Monti's government. Berlusconi and former comedian Beppe Grillo acquire enough votes to create political gridlock in Italy.

- The Economist (2012) argues that France is slowly heading toward a crisis, with government spending about 57 percent of GDP, high and rising public debt, a recent loss of its AAA rating for French sovereign debt, an unemployment rate above the Euro area average, and a steady erosion of its international competitiveness. A fragile France 
implies deep troubles for the Euro area.

- Former Japanese Prime Minister Shinzo Abe returns to office after being turned away following a one-year stint in 2006-2007. The election outcome is, at least in part, a rebuke of Prime Minister Yoshihiko Noda's plans to double the consumption tax by 2015 to help cope with Japan's over-200-percent debt-GDP ratio.

- With the recent marking down of economic growth forecasts in the United Kingdom came the government's decision to postpone achieving the government debt target it had set for itself when Britain's austerity measures were announced. This decision triggered finger-wagging by credit-rating agencies, who accused the government of weakening the credibility of the new fiscal regime.

- Greece's sovereign debt crisis is in its third year and still no lasting resolution is in sight.

- After the debt-ceiling debacle in 2011, political parties in the United States continue to be unable to find common ground on even the most basic fiscal issues. Politicians "solved" the fiscal cliff by postponing several contentious decisions, laying the groundwork for fresh artificial fiscal crises in the coming year, including mandated across-theboard spending cuts and a new debt-ceiling fiasco. America's political morass and its implications were nicely summed up by U.S. Senator Joe Manchin III: "Something has gone terribly wrong when the biggest threat to our American economy is the American Congress" (Steinhauer (2012)).

These vignettes are not conclusive evidence that major economies will hit their fiscal limits anytime soon. But they do give forward-looking economic decision makers reason to doubt that their governments will smoothly implement the fiscal adjustments necessary to keep their countries well away from their fiscal limits.

\section{The Fiscal Limit}

Recent work on sovereign debt default develops model-based fiscal limits, the simplest example of which comes from Bi and Leeper (2012), which builds on Bi (2012). Those papers consider closed-economy models with fixed capital and a proportional tax levied against labor income. Government buys goods and makes lump-sum transfers to private agents. For given government purchase and transfers processes, an economic fiscal limit arises from the peak of the dynamic Laffer curve. Because that peak depends on the state of the economy, the joint distribution of the fundamental disturbances and private agents' optimal decision rules induce a distribution for the maximum sustainable government debt, equaling the discounted present value of maximum primary surpluses, $s^{\max }$. In an environment subject to random disturbances, "maximum debt" is a distribution, not a point.

Let $s_{t}^{\max }\left(z_{t}\right)$ denote the maximum primary surplus in period $t$ as a function of all the exogenous shocks to the economy, $z_{t}$. Conditional on the shocks that hit the economy at $t$, the fiscal limit is defined as the distribution of the real value of government debt, $\mathcal{B}^{*}\left(z_{t}\right)$, 
given by

$$
\mathcal{B}^{*}\left(z_{t}\right) \sim \sum_{T=t}^{\infty} q_{t, T}^{\max }\left(z_{T}\right) s_{T}^{\max }\left(z_{T}\right)
$$

where $q_{t, t+1}^{\max }\left(z_{t+1}\right)$ is the one-period real discount factor when the state of the economy is $z_{t}$ and the discount factor is evaluated at the tax and spending policies that deliver the maximum surplus in state $z_{t}$.

Research on sovereign debt defaults and observation of actual government policy behavior make clear that the decision to default on debt is driven more by the government's willingness, than its ability, to honor its debt obligations. The political calculus behind the default decision is not easily modeled, so we treat the effective fiscal limit, $b_{t}^{*}$, as a random draw from the fiscal limit distribution in (1). If the value of outstanding debt exceeds $b_{t}^{*}$, the government defaults in some well-specified manner. Otherwise, the government raises taxes to meet its debt obligations.

Productivity and government transfers policies can be important sources of uncertainty. Good productivity shocks raise taxable income and shift the revenue-maximizing level of tax rates. Transfers programs may be stable or grow as a share of the economy, depending the prevailing policy regime, and policy can shift between the two types of transfers policies. Growing transfers capture the fiscal implication of aging populations that underlies the debt projections in figures 3 and 4, while stable transfers reflect fiscal reforms. Because current governments cannot commit future governments' decisions, transfers fluctuate between the stable and unstable regimes. If transfers grow for an extended period, government debt will increase, tax rates will rise toward the peak of the Laffer curve and the economy will approach its fiscal limit. But the position and shape of the fiscal limit distribution also change with the non-policy and policy shocks that hit the economy.

Figure 5 reports the cumulative probability distributions for the fiscal limit from an example economy. The left panel plots the distribution conditional on three alternative values of productivity in period $t$ : average, low and high. Productivity shocks are persistent, so the current value portends future values of similar size and induces substantial shifts in the fiscal limit. A debt-GDP ratio of 200 percent implies a probability of hitting the fiscal limit of about 20 percent when productivity is average, 10 percent when productivity is high, and 80 percent when productivity is low.
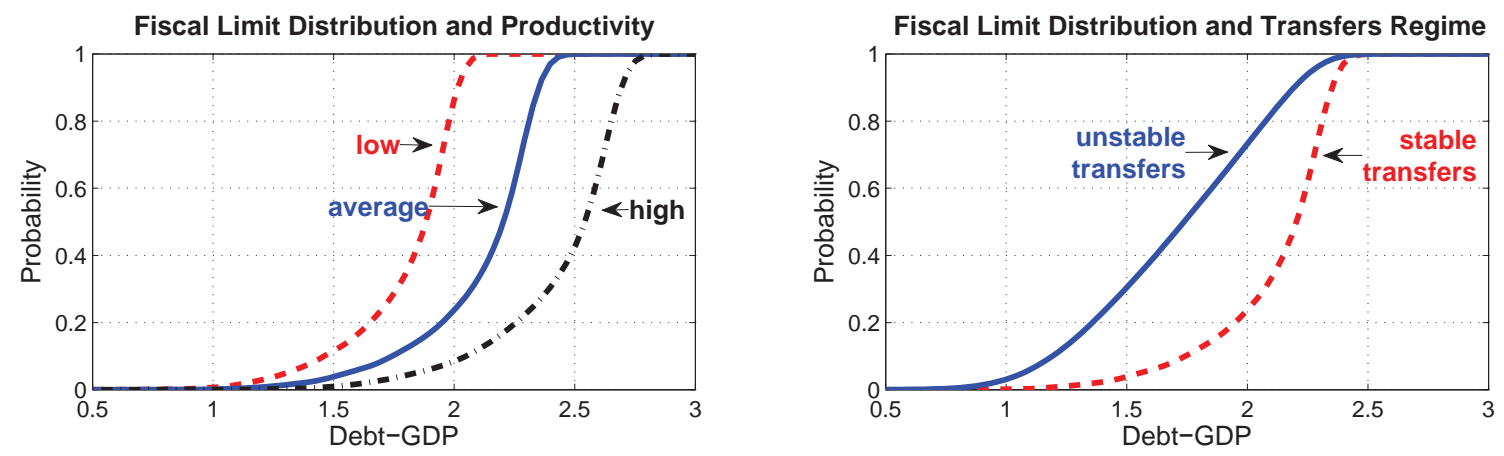

Figure 5: Fiscal limit distribution for example economy. Source: Bi and Leeper (2012) 
The right panel of the figure reports how the fiscal limit distribution shifts with the prevailing transfers regime. When transfers are stable, the economy can support a much higher level of debt without significant probability of breaching the fiscal limit. Unstable transfers growth, like that projected in many advanced economies, dramatically lowers the present value of maximum surpluses, shifting the limit to the left: debt levels like those some countries are now experiencing generate non-trivial probabilities of hitting the limit.

In a complete economic model, the endogenous fiscal limit distribution triggers shifts in agents' expectations and decisions that depend on agents' understandings about how policies will change at the fiscal limit. ${ }^{7}$ Figure 5 merely illustrates the fiscal limit. Limits in actual economies will vary across countries and across time, as they depend on many details of an economy's structure. In what follows, I show how an economy operates when it is at its fiscal limit and opts to allow inflation to devalue outstanding government debt.

\section{Inflation as a Means of Devaluation}

The conventional perception among macroeconomists is that fiscal policy can affect inflation only if the central bank systematically prints money to buy government bonds or to finance government purchases directly. Excessive money growth is Cagan's (1956) explanation of hyperinflations, which Sargent and Wallace (1981) connected directly to fiscal policy at the fiscal limit, where it is unwilling or unable to stabilize debt by adjusting primary surpluses. There is no dispute among economists that by monetizing government debt the central bank creates a channel by which fiscal policy generates inflation.

Missing from this conventional view is the fact that if government debt is denominated in nominal terms, then there is a new channel for fiscal inflation that is unrelated to explicit debt monetization. This new channel, called the "fiscal theory of the price level," is frequently treated as an object of derision by macroeconomists. Although the fiscal theory has been around for over 20 years, it remains a bit mystical to non-specialists. ${ }^{8}$ Monetarist or new Keynesian explanations of inflation, in contrast, are well understood, having been distilled into basic supply and demand analyses that are taught to all economics students. Those explanations typically sweep fiscal policy under the carpet by maintaining strong assumptions about fiscal behavior that render it irrelevant. This conventional view is fully consistent with Friedman's aphorism that "inflation is always and everywhere a monetary phenomenon."

It turns out that the fiscal theory explanation of price-level determination can also be presented in a form that is comprehensible to non-specialists. Understanding how fiscal policy can determine the price level when government debt is nominal requires only a few key economic relationships: budget constraints, asset-pricing relations, and market-clearing conditions. Because these relationships are completely generic - they apply in any formal economic model - the fiscal theory is ubiquitous and potentially obtains in any model.

4.1 A Simple Model To focus on how monetary and fiscal policies determine the price level and the inflation rate, we abstract from production and employment and simply assume

\footnotetext{
${ }^{7}$ Examples of complete models include Bi (2012), Bi and Leeper (2012), and the papers in footnote 17.

${ }^{8}$ Early developments of the fiscal theory include Leeper (1991), Sims (1994), Woodford (1995), and Cochrane (1998). Two examples of authors who ridicule the fiscal theory without offering any coherent arguments against it are Buiter (2002) and Galí (2013).
} 
that the economy is endowed each period with a fixed quantity of output goods, $Y$. We further simplify by abstracting from money: instead, we treat the central bank as choosing a short-term nominal interest rate, $R .^{9}$

Households make a consumption-savings decision each period. They have available three assets: a real one-period bond, $b_{t}$, that pays 1 unit of goods in period $t+1$, sells at price $q_{t, t+1}$ in period $t$, and is in zero net supply; a one-period nominal government bond, $B_{s t}$, that pays 1 unit of currency in $t+1$, sells at price $P_{s t}=R_{t}^{-1}$ in $t$, and is also in zero net supply; long-term nominal government bonds, $B_{m t}$, that sell at price $P_{m t}$ in $t$ and are in non-zero net supply. As in Woodford (2001), long bonds sold at $t$ pay $\rho^{j}$ dollars in each period $t+j+1$ for each $j \geq 0$ with $0 \leq \rho \leq 1$. We interpret these bonds as a portfolio of bonds at all possible maturities with weights along the maturity structure given by $\rho^{T-(t+1)}$. Changing $\rho$ varies the average maturity of the portfolio: when $\rho=0$ all bonds are one-period and when $\rho=1$ all bonds are consols that pay $\$ 1$ every period. The duration of these long bonds is $(1-\beta \rho)^{-1}$.

Optimal choices by the households yield two asset-pricing relations

$$
\begin{aligned}
P_{s t} & =\frac{1}{R_{t}}=E_{t}\left(\frac{P_{t}}{P_{t+1}} q_{t, t+1}\right) \\
P_{m t} & =P_{s t} E_{t}\left(1+\rho P_{m t+1}\right)
\end{aligned}
$$

$P_{t}$ is the price level, so $P_{t} / P_{t+1}$ is the inverse of the gross inflation rate. The first expression, (2), is the usual Fisher relation connecting the short-term nominal interest rate to expected inflation and the real interest rate; it ensures that there are no unexploited arbitrage opportunities between nominal and real bonds. The second expression, (3), is the term structure relationship that links the price of long bonds to the entire expected path of short-bond prices. This term structure relationship, which rules out arbitrage opportunities between short- and long-term nominal bonds, implies that

$$
P_{m t}=\sum_{j=0}^{\infty} \rho^{j} E_{t}\left(\prod_{i=0}^{j} \frac{1}{R_{t+i}}\right)
$$

making it clear that in its setting of an expected path of the short-term interest rate, the central bank determines the price of long-term bonds.

The fiscal authority chooses the current level of the primary (exclusive of interest payments) budget surplus, $s_{t}$, and new bond sales, $B_{m t}$. It also must cover the principal and interest on outstanding debt. These choices must satisfy the government's budget constraint in period $t$

$$
\frac{P_{m t} B_{m t}}{P_{t}}+s_{t}=\frac{\left(1+\rho P_{m t}\right) B_{m t-1}}{P_{t}}
$$

Because this budget constraint also holds in every time period, an analogous constraint holds in period $t+1$

$$
\frac{P_{m t+1} B_{m t+1}}{P_{t+1}}+s_{t+1}=\frac{\left(1+\rho P_{m t+1}\right) B_{m t}}{P_{t+1}}
$$

\footnotetext{
${ }^{9}$ Abstracting from money is consistent with the new Keynesian literature in, for example, Woodford (2003) or Galí (2008), and with most formal models at central banks. Bringing money into the analysis complicates things a bit, but does not alter the key messages, as Leeper and Walker (2013) show.
} 
Notice that the new debt sold in period $t, B_{m t}$, enters the government's constraint in period $t+1$ because it must be serviced, so there is a necessary link between the debt the government sells today and the surplus it runs tomorrow: $B_{m t}$ and $s_{t+1}$ must be related to each other. Extrapolating this logic into the indefinite future leads to an expression that Cochrane (2011) calls the "bond valuation equation"

$$
\frac{\left(1+\rho P_{m t}\right) B_{m t-1}}{P_{t}}=E_{t} \sum_{T=t}^{\infty} q_{t, T} s_{T}
$$

where $q_{t, T}$ is the $(T-t)$-period discount factor with $q_{t, t} \equiv 1$. The market value of outstanding government bonds - the left side of (7) - must equal the expected discounted present value of all future primary surpluses. This is nothing more than a conventional asset-pricing relation applied to government bonds: the value of an asset depends on its expected discounted cash flows. A government bond's "cash flows" are future surpluses after meeting interest payments on the debt. Because government debt derives its value from expected surpluses, condition (7) is a critical step toward developing the demand for government bonds.

Combining the bond valuation equation, (7), with the government's budget constraint, (5), yields an expression for the market value of bonds sold in period $t$

$$
\frac{P_{m t} B_{m t}}{P_{t}}=E_{t} \sum_{T=t+1}^{\infty} q_{t-1, T} s_{T} \equiv E_{t} P V\left(\mathcal{S}_{t+1}\right)
$$

By this version of the bond valuation equation, the value of bonds sold at $t, P_{m t} B_{m t} / P_{t}$, depends on the expected discounted present value of primary surpluses from period $t+1$ onward, abbreviated as $E_{t} P V\left(\mathcal{S}_{t+1}\right)$. The higher is the present value of expected surpluses, the greater is the value of outstanding bonds. Expressions (7) and (8) emerge after imposing that private agents make optimal asset-demand decisions, which include (2) and (3) and the restriction that government debt-GDP must grow at a rate less than the real interest rate.

Because (8) embeds private agents' optimal choices, it constitutes a demand function for nominal government bonds

$$
B_{m t}^{d}=\frac{P_{t}}{P_{m t}} E_{t} P V\left(\mathcal{S}_{t+1}\right)
$$

Two determinants of the nominal demand for bonds are immediate. The higher the price level today, $P_{t}$, or the higher the expected present value of surpluses, $E_{t} P V\left(\mathcal{S}_{t+1}\right)$, the greater is the nominal demand for bonds. Demand also rises when the price of bonds today, $P_{m t}$, falls. A lower price of bonds, through the term structure relation, (4), and the Fisher relation, (2), is associated with a higher path of the short-term nominal interest rate or of the inflation rate. ${ }^{10}$ Because nominal government bonds promise to pay off in currency, rather than in goods, bond demand depends positively on current and future price levels.

\footnotetext{
${ }^{10}$ Three aspects of the demand for nominal bonds are distinguished from the typical demand for nominal money. First, unlike fiat money, bonds are "backed" by future surpluses and, therefore, the demand for bonds depends explicitly on expected fiscal policies. Second, unlike fiat money, bonds pay positive nominal interest and, therefore, are protected from fully anticipated inflation. Higher anticipated inflation drives up the nominal return to bonds and drives down the nominal price of bonds. Third, transactions demand for money introduces a scale variable like income or wealth into money demand, which is absent in this specification of bond demand (but see Canzoneri, Cumby, and Diba (2011) for a description of liquidity demand for bonds).
} 
Bond supply is perfectly inelastic. Given policies, debt inherited from the past, and equilibrium prices, the supply of bonds in period $t$ is whatever it must be to satisfy the government budget constraint (5).

4.2 Determining the Price Level Entire textbooks are written about how the price level gets determined when there is no fiscal limit, so we focus on the opposite case: suppose that for economic or political reasons, the fiscal authority cannot raise (lower) future surpluses whenever the real value of outstanding debt rises (falls). It might still adjust surpluses for reasons other than debt-stabilization: fluctuations in real economic activity might induce automatic or discretionary changes in surpluses or surpluses might change for reasons that are exogenous to the model. For our purposes, we can treat the sequence of primary surpluses, $\left\{s_{t}\right\}$, as an exogenous and possibly random process. Economic agents understand the nature of the randomness, so are able to form expectations over future surpluses. This assumption about fiscal behavior is consistent with an economy that has hit its fiscal limit, just as in Sargent and Wallace (1981).

When surpluses are unresponsive to the state of government indebtedness, if monetary policy were to continue to pursue its objectives in an unconstrained fashion, government debt would grow exponentially and become worthless. For government debt to retain value, monetary policy must accommodate the exogenous surpluses by taking on the role of debt stabilization. In terms of the debt valuation equation (8), $E_{t} P V\left(\mathcal{S}_{t+1}\right)$ no longer adjusts to stabilize debt, so some combination of $P_{t}$ and $P_{m t}$ must do the adjusting: current and expected price levels change to ensure that the real value of debt is consistent with expected surpluses. Because the central bank chooses the sequence of short-term nominal interest rates, $\left\{R_{t}\right\}$, at the fiscal limit monetary policy is constrained to choose interest-rate paths that are consistent with the expected surpluses that the fiscal authority determines. ${ }^{11}$

We can now determine the equilibrium process for the price level. Algebraically, the equilibrium gets determined recursively. At date $t$, monetary policy announces a path for the policy instrument, $\left\{R_{T}\right\}_{T=t}^{\infty}$, which, by the term structure relation, (3) or (4), determines the price of bonds at $t, P_{m t}$. Fiscal policy announces a path for its policy instrument, the primary surplus, $\left\{s_{T}\right\}_{T=t}^{\infty}$. In this model, the real interest rate and, therefore, the price of real bonds, $\left\{q_{T, T+1}\right\}_{T=t}^{\infty}$, is exogenous. The real interest rate and surplus sequences imply the expected present value of surpluses and, by expression (7), determines $P_{t}$. The government's flow budget constraint at $t,(5)$, determines $B_{m t}$. This solution method repeats every period.

Graphically, interaction of supply and demand for nominal bonds determines the price level at $t$. Figure 6 describes bond-market behavior. The government supplies bonds inelastically, $B^{s}$, in order to satisfy its budget constraint. Demand for bonds comes from behavioral relation (9) and slopes upward when the current price level is on the vertical axis. For given paths of expected interest rates and surpluses, nominal bond demand is $B_{1}^{d}$ and the equilibrium price level is $P_{1}$.

When bond supply and demand are drawn as in figure 6, a lower bond price, lower

\footnotetext{
${ }^{11}$ Sargent and Wallace's (1981) unpleasant arithmetic setup also constrains monetary policy choices, but their emphasis is on generating sufficient inflation tax revenues - seigniorage - to "back" the outstanding debt. In terms of debt valuation equation $(8), E_{t} P V\left(\mathcal{S}_{t+1}\right)$ includes seigniorage revenues, so future surpluses defined broadly adjust to stabilize debt. Sargent and Wallace treat debt as real-perfectly indexed to inflation - so price level changes cannot revalue debt.
} 


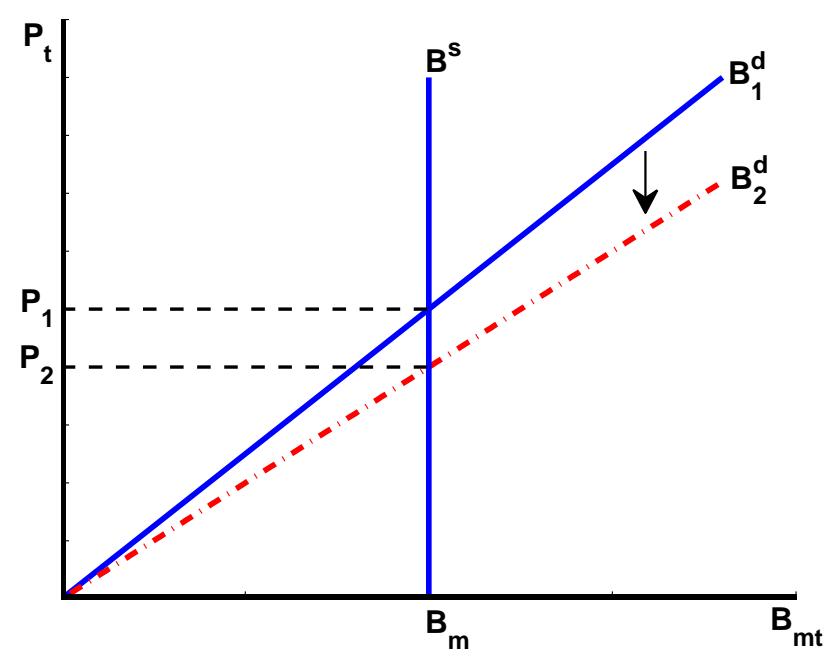

Figure 6: Bond market equilibrium: Supply, $B^{s}$, is inelastic and demand is $B^{d}=$ $\frac{P_{t}}{P_{m t}} E_{t} P V\left(\mathcal{S}_{t+1}\right)$, as in expression (9).

expected path of real interest rates, or higher expected path of primary surpluses pivots the demand for bonds down to the demand function $B_{2}^{d}$ : investors demand more nominal bonds at any given price level. At the initial equilibrium price level, $P_{1}$, after the shift in demand there is excess demand for bonds. Bond holders substitute from buying goods to buying bonds; lower aggregate demand for goods drives down the price level. As the price level falls, demanders slide down $B_{2}^{d}$, reducing the quantity of bonds demanded. The price level falls until the market value of bonds rises to be consistent with the bond valuation equation in $(8)$.

We now use supply and demand for nominal government bonds to examine some specific economic events.

4.3 Some Examples To make the analysis more concrete, we can separate dynamics into "today" (period $t$ ) and the "future" (all periods after $t$ ). We consider the economy today and we hold output and government purchases constant, making the real discount factor constant also: $q_{t, T}=q$ for all $T>t$. Monetary and fiscal policies take simple forms

Monetary Policy : sets a constant short interest rate, $R_{T}=R$ for $T \geq t$

Fiscal Policy : chooses a constant surplus, $s_{T}=s$ for $T \geq t+1$, but $s_{t} \neq s$

Monetary policy just pegs the short-term nominal interest rate at $R$. Fiscal policy holds future surpluses fixed at $s$, but allows the current surplus to differ from that fixed value.

By pegging the nominal interest rate, monetary policy pegs future inflation, $\pi_{F}$, and the price of long bonds

$$
\begin{aligned}
\pi_{T} & =\pi_{F}=q R & & \text { for } T \geq t+1 \\
P_{m T} & =\frac{1}{R-\rho} & & \text { for } T \geq t
\end{aligned}
$$


Constant discount factors and constant future surpluses reduce the expected present value of surpluses in (8) to

$$
E_{t} P V\left(\mathcal{S}_{t+1}\right)=\frac{q}{1-q} s
$$

and the bond valuation equation, (7), to

$$
\frac{\left(1+\rho P_{m t}\right) B_{m t-1}}{P_{t}}=s_{t}+\frac{q}{1-q} s
$$

We can use (11) and (13) to solve for the equilibrium price level

$$
P_{t}=\left(\frac{R}{R-\rho}\right) \frac{B_{m t-1}}{s_{t}+\frac{q}{1-q} s}
$$

Collecting the model's implications, based on the expression for the equilibrium price level, (14), a higher current price level (and current inflation rate) arises from

1. a lower path for short-term nominal interest rates (though future inflation will be lower)

2. a longer average maturity of government bonds

3. a higher initial debt level

4. a lower path for real discount factors (or a higher path for real interest rates)

5. lower current or future primary surpluses

4.3.1 Bond-Financed Tax Cut Suppose that to respond to an economic downturn, the government cuts taxes today and finances the resulting deficit with new bond sales. In figure 7 , this shifts bond supply to the right (from $B_{1}^{s}$ to $B_{2}^{s}$ ). With the economy at its fiscal limit, future surpluses do not change, so $E_{t} P V\left(\mathcal{S}_{t+1}\right)$ remains at its initial value in equation (12). Private agents who receive the tax cut and do not expect any subsequent tax increases, feel wealthier and try to convert their tax cut into higher consumption of goods and services. In this model economy, higher aggregate demand does not bring forth greater production, so the prices of goods begin to rise. A higher price level induces bond holders to increase their nominal bond holdings, a process that continues until all the new bond issuances have been absorbed and the price level rises to $P_{2}$ in figure 7 , where the real value of outstanding debt has not changed: $B_{1} / P_{1}=B_{2} / P_{2} \cdot{ }^{12}$

But this analysis is not complete without specifying how monetary policy behaves. The outcome in figure 7 assumes that the central bank maintains the interest-rate peg at the initial $R$, so that the price of bonds does not change from the value in equation (11) and future inflation is unchanged from the value in (10). The fixed bond price together with an unchanged present value of surpluses ensure bond demand does not shift and the full increase in prices occurs today.

\footnotetext{
${ }^{12}$ Conventional new Keynesian analyses posit Ricardian fiscal behavior, so a tax cut today engenders an exactly offsetting increase in the present value of future taxes. This pivots bond demand down by exactly the amount of the the increase in bond supply, ensuring that the equilibrium price level remains at $P_{1}$.
} 


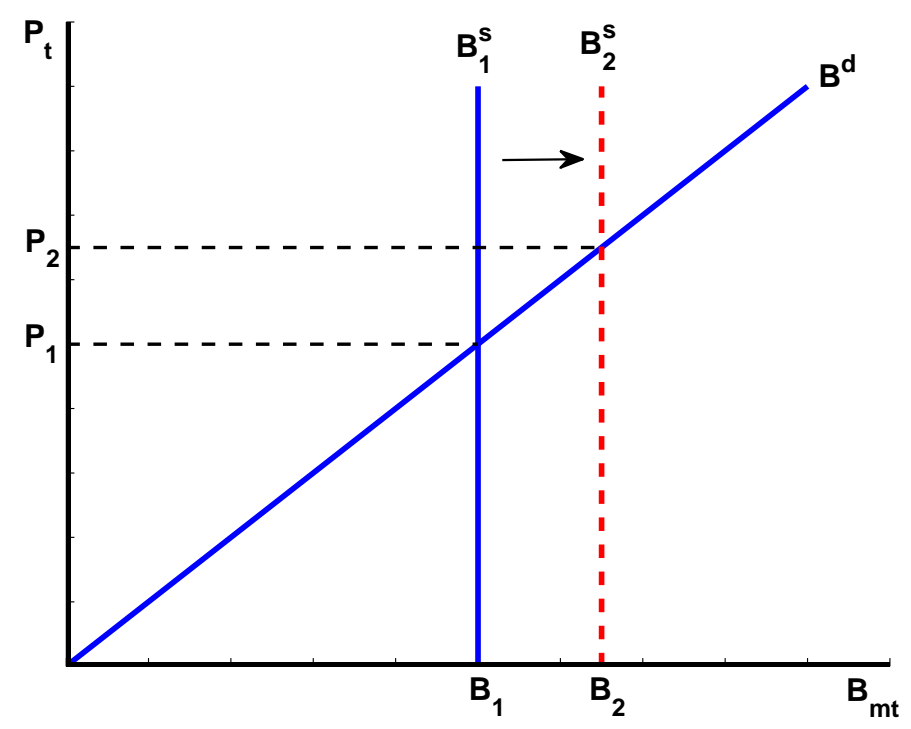

Figure 7: Bond-financed tax cut today. Bond supply shifts to the right. If central bank keeps nominal interest rate and, therefore, bond prices unchanged, there is no shift in bond demand, the price level rises to $P_{2}$ and the real quantity of bonds is unchanged: $B_{1} / P_{1}=B_{2} / P_{2}$.

But an inflation-targeting central bank is likely to react to the fiscally-induced increase in current inflation by raising the nominal policy interest rate. A higher path for $R$ reduces bond prices today and raises expected inflation. Lower $P_{m t}$ increases nominal bond demand, so demand pivots down to $B_{2}^{d}$, as in figure 8 . Higher bond demand attenuates the rise in current inflation. Although monetary policy cannot eliminate the fiscal inflation, by adjusting the nominal interest rate it can determine the timing of fiscal inflation.

At the fiscal limit, fiscal policy determines the total inflation in the economy, while monetary policy determines its timing. To see this, combine expressions (10) and (14) to reveal the tradeoff between current and future inflation

$$
\pi_{t}\left(1-\frac{\rho q}{\pi_{F}}\right)=\frac{B_{m t-1} / P_{t-1}}{s_{t}+\frac{q}{1-q} s}
$$

For a given value of the right side of $(15)$, it is clear that higher current inflation $\left(P_{t}\right)$ is associated with lower future inflation $\left(\pi_{F}\right)$. This tradeoff appears graphically in figure $9 .{ }^{13}$

4.3.2 Low Real Interest Rates Demand for bonds will also shift with changes in investors' beliefs about the future backing of bonds. That backing depends on fiscal policy behavior through future primary surpluses, but it also depends on the expected path of real interest rates that serve to discount surpluses. Short-term real interest rates have been negative in the United States for more than four years, as they were for the decade of the

\footnotetext{
${ }^{13}$ Figure 9 is drawn using the following parameter choices: $q=.9804$ ( $2 \%$ real rate), $B_{m t-1} / P_{t-1}=0.5$, and baseline current and future inflation of $2 \%$.
} 


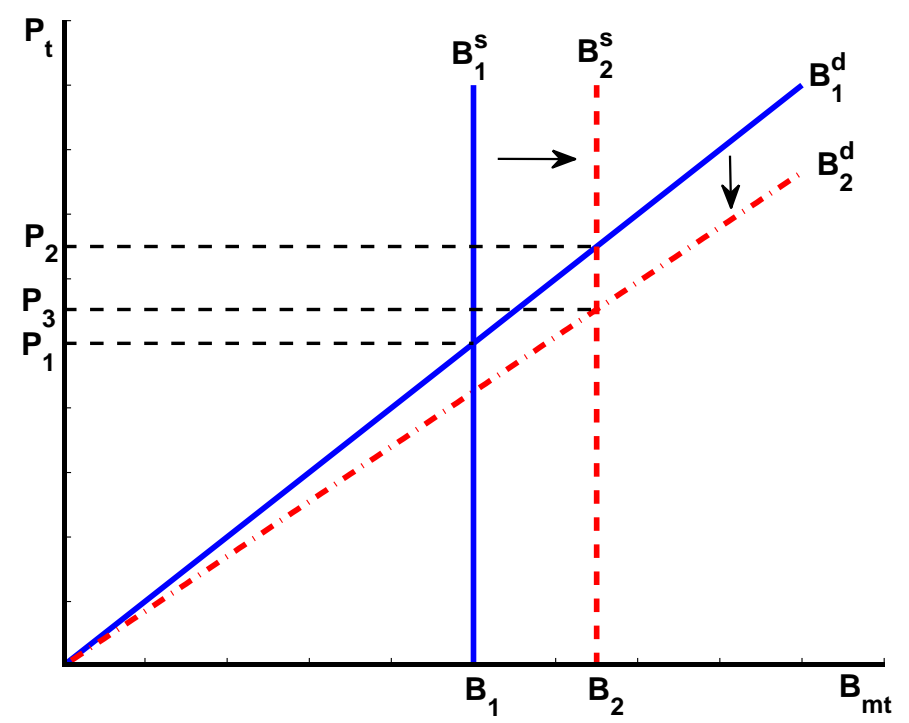

Figure 8: Bond-financed tax cut today. Bond supply shifts to the right. If central bank raises nominal interest rate in response to higher inflation today, bond prices fall and demand for nominal bonds shifts down, attenuating some of the increase in inflation today. Instead, inflation is pushed into the future.

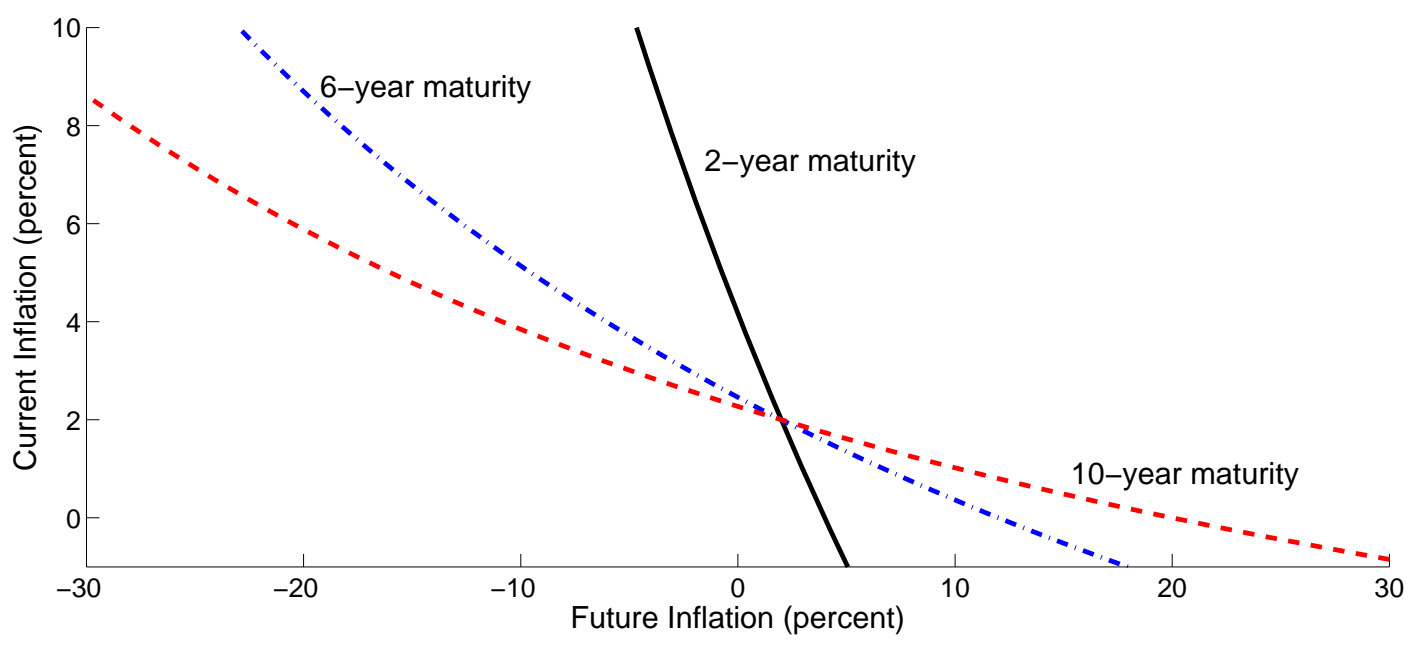

Figure 9: Tradeoff between current and future inflation: Given a level of real debt and present value of surpluses in (15), the higher is inflation today, $P_{t}$, the lower is future inflation, $\pi_{F}$, a tradeoff that varies with the average maturity of government debt.

1970 s and the first half of the 2000s. In terms of the model, negative real interest rates make the discount factors, $q_{t, t+1}$, that discount surpluses in (7) temporarily greater than unity, 
substantially raising the present value of any given stream of future surpluses. ${ }^{14}$ This raises the value of government debt and pivots down the demand from $B_{1}^{d}$ to $B_{2}^{d}$ in figure 10 to reduce the current price level.

Persistently low real rates may explain why the United States is not experiencing a pickup in inflation despite the massive expansion in nominal government debt of recent years. If the fiscal inflation mechanism that this paper highlights is at work in the United States, then inflation is not likely to begin to rise until real interest rates have returned to more normal levels. But a return to normalcy in the world economy remains elusive and is intrinsically difficult to predict. In the face of a fiscal limit, normalcy may signal a move by investors out of treasuries, with the resulting increases in aggregate demand and inflation.

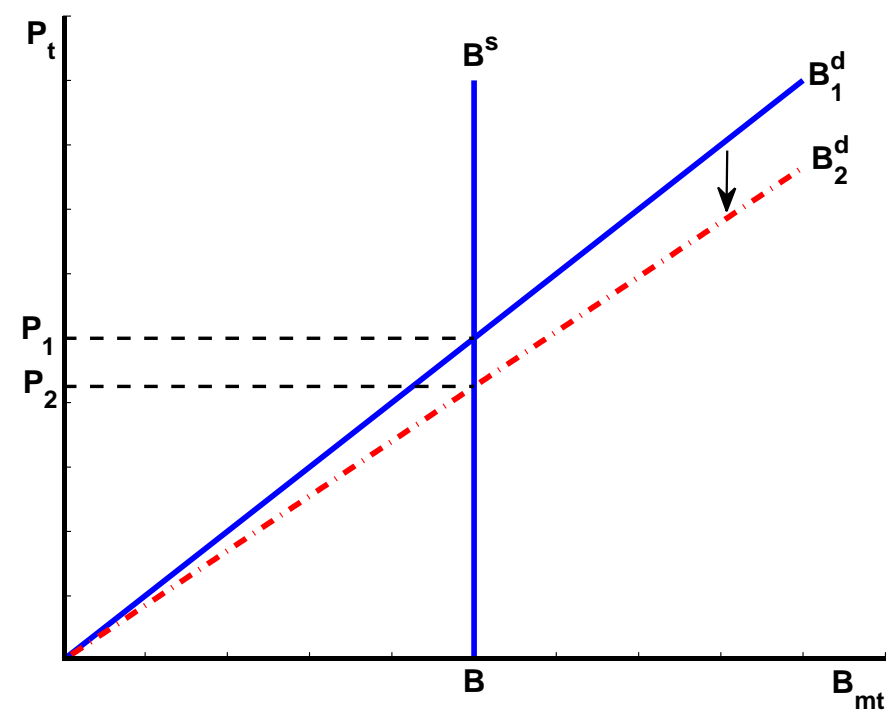

Figure 10: Lower real interest rates. Expected present value of any given stream of surpluses increases, pivoting demand for bonds down to $B_{2}^{d}$ and reducing current inflation.

4.3.3 Subtle Inflation Effects Fiscally-induced inflation can be tricky to detect in data. The bond-financed tax cut shows that whether inflation occurs coincident with the tax cut or occurs for many years after the tax cut depends on how monetary policy responds to fiscal policy. It also depends on the maturity structure of government debt, which in actual economies varies over time.

Changes in real interest rates can also produce inflation in an economy at its fiscal limit. But both the mechanism and the direction of the effects differ sharply from in conventional new Keynesian analyses. Conventional analyses posit that higher real rates choke off aggregate demand and reduce inflation. At the fiscal limit, higher real rates lower the present value of surpluses, which reduces the value of debt and raises aggregate demand and inflation.

Inflation can even occur before the fiscal changes that cause the inflation. News of lower future taxes or higher future government transfer payments reduces the expected present

\footnotetext{
${ }^{14}$ Discount factors cannot exceed unity forever in a dynamically efficient equilibrium.
} 
value of surpluses and induces agents to move today from holding bonds into buying goods. Higher aggregate demand can raise inflation well before the fiscal changes take effect. Empirical work that presumes fiscal actions precede inflation will fail to uncover evidence of fiscal inflation.

\section{Speculation About the American Fiscal Limit}

U.S. government debt continues to serve as a safe haven for investors and the U.S. dollar still plays the role of a reserve currency in the world economy. But in recent years the United States has also experienced one of the largest expansions in government debt and that expansion has been accompanied by severe political paralysis. These developments raise the question of whether America faces the prospect of hitting a fiscal limit, making debt-stabilizing adjustments in surpluses less than assured. I believe that devaluation via inflation is far more likely in the United States and possibly even other advanced economies than is outright default.

Framers of the U.S. Constitution understood the importance of adopting credible future financing for government debt and some key players in the country's early history expounded on the disastrous consequences of outright default. ${ }^{15}$ Here are some selected quotations:

"... No pecuniary consideration is more urgent than the regular redemption and discharge of the public debt: on none can delay be more injurious, or an economy of the time more valuable."

George Washington, 1793

"... proper funding of. . . debt [is]... a national blessing ...."

"... public debts are public benefits ...."

"... creation of debt should always be accompanied with the means of extinguishment."

"... arguments for [honoring debt] rest on the immutable principles of moral obligation."

Alexander Hamilton, 1790

To the extent that American political leaders continue to regard debt repayment as a "moral obligation," it seems unlikely that the United States will follow in the footsteps of countries that have reneged on their debt obligations.

On the other hand, U.S. political developments over the past few decades do not make me sanguine about the prospects for orderly fiscal reforms going forward. Political scientists have noted that for the past 30 years, the major American political parties have become increasingly polarized, a trend that has accelerated recently. ${ }^{16}$ Figure 11 summarizes the distance between political parties in the U.S. Congress based on roll call votes.

Two aspects of the figure are striking. First, political polarization is at an all-time high and has been rising steadily since about 1980. Second, past times of national crisis - the

\footnotetext{
${ }^{15}$ Sargent (2012) provides a thoughtful historical account and ties the U.S. experience to current issues that Europe faces.

${ }^{16}$ See, for example, Mann and Ornstein (2006, 2012), McCarty, Poole, and Rosenthal (2006), Theriault (2008), Lofgren (2012), and Silver (2012).
} 


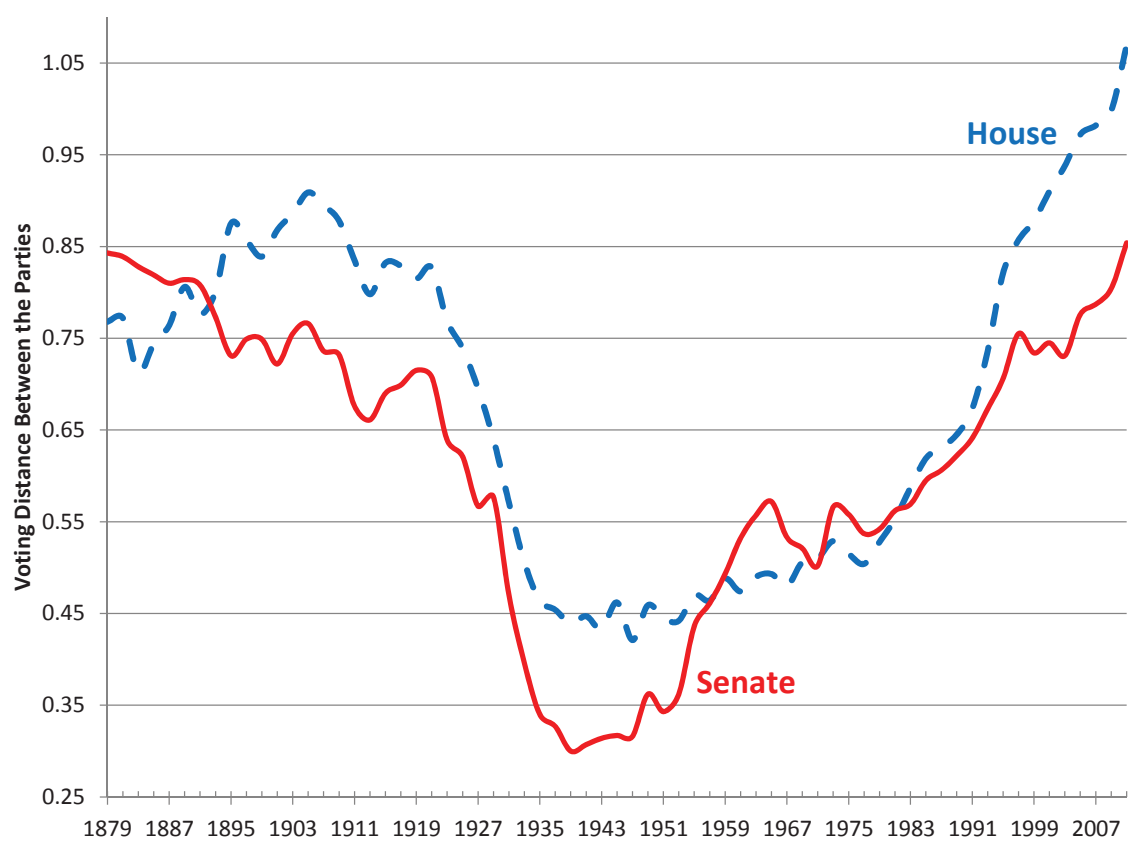

Figure 11: U.S. political party polarization 1879-2012. Measured as the difference in party means of roll call votes. Source: Poole and Rosenthal (2012)

Great Depression, the two world wars - brought the political parties together, while the latest financial crisis and large recession drove them farther apart. Political scientists offer alternative theories to explain the increase in polarization, with some ascribing the rise to particular political personalities, while others attribute it to gradual demographic shifts among the electorate. Whatever the source of rising political polarization, it does not bode well for how the United States will resolve its long-run fiscal stress. For thinking about fiscal inflation, what matters is that Americans believe it is possible that extended political paralysis will push the economy closer to its fiscal limit, where fiscal policy cannot be relied upon to adjust surpluses to stabilize debt.

To keep the theory simple, section 4 adopts the stark assumption that the economy is at its fiscal limit and people expect it to remain there forever. But recent papers show, more realistically, that so long as there is some probability of hitting the fiscal limit, even temporarily, the broad implications of the stark theory carry through. ${ }^{17}$ More realistic settings moderate fiscal effects on inflation, but it continues to be true that monetary policy can do nothing to offset the fiscal impacts.

The presence of a fiscal limit dramatically changes how the price level and inflation rate get determined. Of course, the political process that determines fiscal choices and the distance of the economy from its fiscal limit are beyond the control of independent central bankers, aside from efforts to jawbone elected officials into adopting debt-stabilizing fiscal policies. Prudent central bankers, though, might wish to think through what the appropriate

\footnotetext{
${ }^{17}$ Papers that explore the more general policy setting include Chung, Davig, and Leeper (2007), Davig and Leeper (2006, 2011), Davig, Leeper, and Walker (2010, 2011), Bianchi (2011), Bianchi and Ilut (2012), Sims (2011), and Eusepi and Preston (2011, 2012).
} 
monetary policy is for a country that is staring at its fiscal limit. 


\section{REFERENCES}

Bi, H. (2012): "Sovereign Risk Premia, Fiscal Limits and Fiscal Policy," European Economic Review, 56(3), 389-410.

Bi, H., And E. M. Leeper (2012): “Analyzing Fiscal Sustainability," Manuscript, Indiana University, October.

Bianchi, F. (2011): "Regime Switches, Agents' Beliefs, and Post-World War II U.S. Macroeconomic Dynamics," Manuscript, Duke University, April.

Bianchi, F., And C. Ilut (2012): "Monetary/Fiscal Policy Mix and Agents' Beliefs," Manuscript, Duke University, April.

Buiter, W. H. (2002): "The Fiscal Theory of the Price Level: A Critique," Economic Journal, 112(481), 459-480.

Cagan, P. (1956): "The Monetary Dynamics of Hyperinflation," in Studies in the Quantity Theory of Money, ed. by M. Friedman, pp. 25-117. University of Chicago Press, Chicago.

Canzoneri, M. B., R. E. Cumby, and B. T. Diba (2011): "The Interaction Between Monetary and Fiscal Policy," in Handbook of Monetary Economics, ed. by B. M. Friedman, and M. Woodford, vol. 3B, pp. 935-1000. Elsevier, Amsterdam.

Cecchetti, S. G., M. S. Mohanty, and F. Zampolli (2010): "The Future of Public Debt: Prospects and Implications," BIS Working Papers No. 300, Monetary and Economic Department, March.

Chung, H., T. Davig, and E. M. Leeper (2007): "Monetary and Fiscal Policy Switching," Journal of Money, Credit and Banking, 39(4), 809-842.

Cochrane, J. H. (1998): "A Frictionless View of U.S. Inflation," in NBER Macroeconomics Annual 1998, ed. by B. S. Bernanke, and J. J. Rotemberg, vol. 14, pp. 323-384. MIT Press, Cambridge, MA.

- (2011): "Determinacy and Identification with Taylor Rules," Journal of Political Economy, 119(3), 565-615.

Congressional Budget Office (2010): The Long-Term Budget Outlook. U.S. Congress, Washington, D.C., June.

Davig, T., And E. M. Leeper (2006): "Fluctuating Macro Policies and the Fiscal Theory," in NBER Macroeconomics Annual 2006, ed. by D. Acemoglu, K. Rogoff, and M. Woodford, vol. 21, pp. 247-298. MIT Press, Cambridge.

- (2011): "Temporarily Unstable Government Debt and Inflation," IMF Economic Review, 59(2), 233-270.

Davig, T., E. M. Leeper, And T. B. Walker (2010): “Unfunded Liabilities' and Uncertain Fiscal Financing," Journal of Monetary Economics, 57(5), 600-619. 
(2011): "Inflation and the Fiscal Limit," European Economic Review, 55(1), 31-47.

Eusepi, S., And B. Preston (2011): "Learning the Fiscal Theory of the Price Level: Some Consequences of Debt-Management Policy," Journal of the Japanese and International Economies, 25(4), 358-379.

- (2012): "Fiscal Foundations of Inflation: Imperfect Knowledge," Manuscript, Monash University, October.

Galí, J. (2008): Monetary Policy, Inflation, and the Business Cycle. Princeton University Press, Princeton.

(2013): "Comment," in Fiscal Policy After the Financial Crisis, ed. by A. Alesina, and F. Giavazzi, pp. 299-310. University of Chicago Press, Chicago.

Ghosh, A., J. I. Kim, E. G. MendozA, J. D. Ostry, and M. S. Qureshi (2012): "Fiscal Fatigue, Fiscal Space and Debt Sustainability in Advanced Economies," The Economic Journal, 123(566), F4-F30.

International Monetary Fund (2012a): World Economic Outlook. IMF, Washington, D.C., October.

(2012b): World Economic Outlook. IMF, Washington, D.C., April.

Leeper, E. M. (1991): “Equilibria Under 'Active' and 'Passive' Monetary and Fiscal Policies," Journal of Monetary Economics, 27(1), 129-147.

Leeper, E. M., And T. B. Walker (2013): "Perceptions and Misperceptions of Fiscal Inflation," in Fiscal Policy After the Financial Crisis, ed. by A. Alesina, and F. Giavazzi, pp. 255-299. University of Chicago Press, Chicago.

Lofgren, M. (2012): The Party Is Over: How Republicans Went Crazy, Democrats Became Useless, and the Middle Class Got Shafted. Viking, New York.

Mann, T. E., And N. J. Ornstein (2006): The Broken Branch: How Congress is Failing American and How to Get It Back on Track. Oxford University Press, New York.

(2012): It's Even Worse Than It Looks: How the American Constitutional System Collided with the New Politics of Extremism. Basic Books, New York.

McCarty, N., K. T. Poole, and H. Rosenthal (2006): Polarized America: The Dance of Ideology and Unequal Riches. The MIT Press, Cambridge, MA.

Poole, K., And H. Rosenthal (2012): "Party Polarization: 1879-2011," May 10, http://voteview.com/political_polarization.asp.

Sargent, T. J. (2012): "United States Then, Europe Now," Nobel Lecture, Manuscript, New York University, February. 
Sargent, T. J., And N. Wallace (1981): "Some Unpleasant Monetarist Arithmetic," Federal Reserve Bank of Minneapolis Quarterly Review, 5(Fall), 1-17.

Silver, N. (2012): "As Swing Districts Dwindle, Can a Divided House Stand?," FiveThirtyEight, New York Times Blog, December 27, http://fivethirtyeight.blogs.nytimes.com/2012/12/27/as-swing-districts -dwindle-can-a-divided-house-stand.

Sims, C. A. (1994): "A Simple Model for Study of the Determination of the Price Level and the Interaction of Monetary and Fiscal Policy," Economic Theory, 4(3), 381-399.

(2011): "Stepping on a Rake: The Role of Fiscal Policy in the Inflation of the 1970's," European Economic Review, 55(1), 48-56.

— (2013): "Paper Money," forthcoming in American Economic Review, Presidential Address, January.

Steinhauer, J. (2012): "A Wall Built Long and Tall," The New York Times, December 31, p. A1.

The Economist (2012): "So Much to Do, So Little Time," November 17.

Theriault, S. M. (2008): Party Polarization in Congress. Cambridge University Press, New York.

Trabandt, M., And H. Uhlig (2011): "The Laffer Curve Revisited," Journal of Monetary Economics, 58(4), 305-327.

Woodford, M. (1995): "Price-Level Determinacy Without Control of a Monetary Aggregate," Carnegie-Rochester Conference Series on Public Policy, 43, 1-46.

- (2001): "Fiscal Requirements for Price Stability," Journal of Money, Credit, and Banking, 33(3), 669-728.

- (2003): Interest and Prices: Foundations of a Theory of Monetary Policy. Princeton University Press, Princeton, N.J.

World BANK (2012): "Age Dependency Ratio (\% of Working-Age Population)," http://data.worldbank.org/indicator/SP.POP.DPND. 